\title{
Assessment of Effectiveness of Organo-Mineral Fertilizer Made of Coffee Spent Grounds and Biomass Ash
}

\author{
Tomasz Ciesielczuk', Czesława Rosik-Dulewska', Joanna Poluszyńska², \\ Ewelina Ślęzak ${ }^{2}$ \\ 1 Institute of Environmental Protection and Development, Opole University, ul. Oleska 22, 45-052 Opole, \\ Poland \\ 2 Institute of Ceramics and Building Materials, ul. Oświęcimska 21, 45-641 Opole, Poland \\ *Corresponding author's e-mail: tciesielczuk@uni.opole.pl
}

\begin{abstract}
Optimization of the biodegradable wastes management is one of the main goals of the activities taken up in the European Union. The aim of the present paper is to define the possibilities of supporting the process of golden rod yield (Solidago canadensis L.) by using different mineral-organic fertilizers, in a form of granulated substances, produced from extracted coffee wastes (CSG) as well as from ash which is the result of woody biomass combustion. Golden rod, as a potential energetic plant, is very easy to grow because it covers the grounds which are not utilized agriculturally or the ones localised in the close neighbourhood of industrial areas. For certain experimental purposes, a field experiment was conducted. Six experimental plots constituted its basis, two experimental fertilizers based on the extracted coffee wastes (in the amount of $100 \mathrm{~g} / \mathrm{m}^{2}$ ), ash from the process of thermal biomass transition and two commercial fertilizers were applied. After 160 days of the experiment, the golden rod harvest was submitted to quantitative-qualitative analysis. An analysis of basic soil parameters (pH, EC, TOC) was also carried out and the content of significant elements, as far as fertilizers are concerned, $\mathrm{N}, \mathrm{P}, \mathrm{K}, \mathrm{Ca}, \mathrm{Mg}$ was analysed too. As a result of the conducted experiment, the yield rise was observed, both in the case of the plants fed with commercial fertilizers as well as the ones cultivated on the basis of the extracted wastes. Using fertilizers does not only allow for management of the wastes produced in farm areas but also enables to increase the achieved amount of golden rod crops as well as to boost energy that is sourced in the process of biomass used for energetic purposes.
\end{abstract}

Keywords: fertilizer, coffee spent grounds, Solidago, yield, energy

\section{INTRODUCTION}

The aim of sustainable fertilization is quite significant, not only from the point of view of ecological cultivation. The application of residual biomass and the mineral wastes instead of traditional mineral or organic-mineral ones allows for reducing the production costs, contributing to a decrease of landfill waste emplacement at the same time. The residual biomass that comes from the food industry is an attractive form of raw material used for biogas production that can be also used as a fertilizer, after its slight modification. Extracted coffee wastes are produced in large quantities because of the considerable coffee consumption. The annual coffee consumption in Poland is constantly increasing and today it amounts to $3 \mathrm{~kg} /$ person. However, this number, is a few times smaller than in the Scandinavian countries, where the consumption reaches up to $12 \mathrm{~kg} / \mathrm{person} / \mathrm{a}$ (Ciesielczuk et al. 2015). In households, these wastes are discarded to containers with mixed wastes or directed to the containers with biodegradable fraction. Extracted coffee (CSG) contains a wide range of valuable organic compounds, including for example tannin, cellulose, hemicelluloses, polyphenols and organic acids; therefore, it is often used for 
biochar production, for composting as a sorbent and for biodiesel as well (Ballesteros et al. 2014, Mussato et al. 2011, Sampaio et al. 2013). However, these are high-priced technologies demanding the use of significant quantities of fossil fuels (Caetano et al. 2014, Pujol et al. 2013).

Using the CSG waste for fertilizing purposes is hardly ever practiced for the reason of its toxic character in relation to the seedlings of cultivated plants and difficulties in easily putrescible material management. The material is quite problematic when it comes to its collection in the amount that is sufficient to fertilize plants in the camp crops effectively. Nevertheless, due to the possibility of mixing it with an alkaline ash from biomass burning and forming it into granules, it can be used as a fertilizer with high content of organic substances (Ciesielczuk et al. 2017). Applying a fertilizer in the area of single-species golden rod population provides the possibility of a crop increase, which is very beneficial as far as using golden rod biomass as solid fuel is concerned. It also constitutes the alternative for fossil fuels and the woody biomass (Ciesielczuk et al. 2016).

The aim of the present paper was to use the combination of a CSG waste with ash from thermal biomass transition to fertilizing purposes. The process of fertilizing the field of Canadian golden rod (Solidago canadensis L.) growing on the wasteland was supposed to boost the crops of a dry golden rod mass and finally to reach a greater energy amount during the thermal transformation in a central heating boiler.

\section{MATERIAL AND METHODS}

In order to test the effectiveness of fertilization with a mixture of CSG and ash from the thermal incineration of biomass, experimental fields were established. They were carried out on uncultivated lands, where the local golden rod (Solidago canadensis L.) had appeared there spontaneously many years earlier. The studied area has not been cultivated for many years and the single-crop population of Canadian golden rod is an invasive species there. In order to define the basic soil characteristics, before the start of the experiment and after the vegetation period (March), the arable layer $(25 \mathrm{~cm})$ was sampled in 3 places selected at random, on the area intended for experimental fields. At each of the selected sites, 10 single samples were taken and combined to form an aggregate sample. In the soil samples, the $\mathrm{pH}(\mathrm{CP}-315 \mathrm{pH}$ meter $)$ and electrolytic conductivity (CC -102 Elmetron) were determined. Additionally, the following parameters were measured: TOC, TN, (CHNS Elementar analyser), TP (according to norm PN-Z-15011-3;2001), potassium, calcium and sodium (FES method with BWB-XP analyser) and magnesium (AAS method after wet microwave mineralisation with aqua regia). Morphological differentiation was also determined in the samples by means of the sieve analysis.

In the field experimentation carried out, selected commercial fertilizers were used, biomass ash and two types of granular fertilizers produced in the laboratory, including CSG waste and biomass ash in its composition.

Commercial autumn fertiliser available on the market, for experimental purposes was marked with the NJ symbol, commercial non-nitrogen phosphorus fertilizer ( $\mathrm{S}$ ), ash from thermal biomass treatment $(\mathrm{P})$, experimental fertiliser (K10) and experimental fertiliser (K13). The method of $\mathrm{K} 10$ and $\mathrm{K} 13$ fertilizers production was presented in detail in the publication of Ciesielczuk et al. (2017). The chemical characteristics of the applied fertilizers are presented in Table 1.

The fertilizers were applied in spring (April) and spread evenly in the amount of $100 \mathrm{~g} / \mathrm{m}^{2}$ in three independent repetitions. Three plots of land without fertilization were used as a blank. As calculated, the applied dose corresponded to $1000 \mathrm{~kg}$ of fertilizer per ha of field. The fertilizers sown were not mixed with the top soil layer. The field experiment was conducted for 160 days. On the last day of the experiment, goldenrods were harvested from the experimental plots by determining the yield of fresh mass (60 individuals were randomly chosen, then they were measured and weighed as fresh and completely dry) and by analyzing the content of $\mathrm{C}, \mathrm{H}, \mathrm{N}, \mathrm{S}$ (CHNS Elementar analyzer) of the surface part (shoots) of the collected plants. Moreover, the combustion heat was determined by means of a calorimetric bomb.

\section{RESULTS AND DISCUSSION}

\section{Fertiliser characteristics}

The main difference in the composition of applied fertilizers is over $90 \%$ content of organic matter in the K10 and K13 fertilizers and its small amount in the other applied fertilizers. High electrolytic conductivity, which may have 
Table 1. Characteristics of fertilizers used in field experiment

\begin{tabular}{|l|c|c|c|c|c|}
\hline \multicolumn{1}{|c|}{ Specification } & $\mathrm{K} 10$ & $\mathrm{~K} 13$ & $\mathrm{P}$ & $\mathrm{NJ}$ & $\mathrm{S}$ \\
\hline $\mathrm{pH}_{\mathrm{H} 2 \mathrm{O}}$ & $7.04-7.07$ & $7.15-7.20$ & $11.45-11.49$ & 4.21 & 8.70 \\
\hline $\mathrm{pH}_{\mathrm{KCl}}$ & $6.97-7.07$ & $6.31-6.45$ & $11.31-11.36$ & 4.24 & 9.05 \\
\hline $\mathrm{EC}[\mathrm{mS} / \mathrm{cm}]$ & $2.42(0.05)$ & $4.23(0.10)$ & $12.13(0.04)$ & 59.0 & 56.1 \\
\hline Organic matter [\%] & $91.6(0.4)$ & $92.7(0.06)$ & $2.4(0.2)$ & $1.3(0.2)$ & $10.1(0.7)$ \\
\hline $\mathrm{TOC}[\%]$ & $46.6(3.12)$ & $45.15(3.03)$ & $0.02(0.01)$ & $0.52(0.04)$ & $7.8(0.6)$ \\
\hline Kiejdahl nitrogen [\%] & $3.36(0.38)$ & $4.18(0.65)$ & $0.02(0.01)$ & $2.25(0.3)$ & $0.05(0.01)$ \\
\hline $\mathrm{C} / \mathrm{N}$ & 13.9 & 10.8 & 0.4 & 0.23 & 156 \\
\hline $\mathrm{CaO}[\mathrm{g} / \mathrm{kg} \mathrm{dm}]$ & $14.9(0.36)$ & $10.3(1.27)$ & $343.1(4.6)$ & 129.3 & 5.456 \\
\hline $\mathrm{MgO}[\mathrm{g} / \mathrm{kg} \mathrm{dm}]$ & $7.76(0.06)$ & $16.6(0.2)$ & $46.7(4.1)$ & $452(26)$ & $147(21)$ \\
\hline $\mathrm{Na}_{2} \mathrm{O}[\mathrm{g} / \mathrm{kg} \mathrm{dm}]$ & $0.37(0.04)$ & $0.94(0.06)$ & $1.98(0.6)$ & $0.48(0.2)$ & $7.57(0.4)$ \\
\hline $\mathrm{K}_{2} \mathrm{O}[\mathrm{g} / \mathrm{kg} \mathrm{dm}]$ & $9.97(0.08)$ & $5.28(0.26)$ & $82.2(3.6)$ & 177.7 & 586.5 \\
\hline $\mathrm{P}_{2} \mathrm{O}_{5}[\mathrm{~g} / \mathrm{kg} \mathrm{dm}]$ & $7.35(0.09)$ & $7.99(0.11)$ & $16.7(1.8)$ & 89.8 & 263.2 \\
\hline
\end{tabular}

a toxic effect on the crop, is characteristic basically for commercial fertilizers and ash (Golcz and Komosa 2006). The minerals released into a solution in large quantities can be washed out by precipitation in a short time, so commercial fertilisers and ashes should be divided into 2-3 doses and also used in a form of top dressing to avoid the losses on the way of eluting. The fertilisers used in the experiment have diversified $\mathrm{pH}$. The NJ fertiliser is acidic, the $\mathrm{S}$ - slightly alkaline and the $\mathrm{P}$ - strongly alkaline. The experimental fertilizers K10 and K13 were designed in such a way that their $\mathrm{pH}$ is close to neutral (Ciesielczuk et al. 2017). Due to a small amount of nitrogen in $\mathrm{K} 10$ and $\mathrm{K} 13$ fertilisers (mainly derived from organic matter), nitrogen-free commercial fertilisers (NJ and S) intended for autumn use were chosen for comparisons.

\section{Granulometric composition}

The granulometric composition of the tested soil (Table 2) qualifies it for sandy clays. The $\mathrm{pH}$ of soil on the experimental plots ranged from slightly acidic to a neutral, and the soil was characterized by permeability, which facilitates the process of nutrients leaching deep into the pro-

Table 2. Granulometric composition of soil samples from experimental area

\begin{tabular}{|c|c|c|c|}
\hline \multirow{2}{*}{$\begin{array}{c}\text { Grain diamiter } \\
{[\mathrm{mm}]}\end{array}$} & \multicolumn{3}{|c|}{ Share of granulometric fractions [\%] } \\
\cline { 2 - 4 } & 1 & 2 & 3 \\
\hline$>2.0$ & 4 & 6 & 5 \\
\hline$>1.0$ & 15 & 17 & 14 \\
\hline$>0.500$ & 28 & 31 & 34 \\
\hline$>0.250$ & 33 & 28 & 30 \\
\hline$>0.100$ & 16 & 15 & 14 \\
\hline$<0.100$ & 4 & 3 & 3 \\
\hline
\end{tabular}

file. The use of K10 and K13 fertilisers with a high content of organic matter derived from CSG should improve the buffer properties and increase the capacity of a sorption complex of soil.

The effect of the one-off fertilisation on the soil properties, after 160 days from the moment of the fertiliser's dose application, is particularly interesting. A slight increase in the electrolytic conductivity was observed in the tested soil samples (Table 3), but with the exception of the K10 fertilizer.

The highest conductivity was observed in the field where the experimental fertilizer K13, containing a significant amount of magnesium sulphate, was applied. This fertilizer is characterized by a relatively high salinity of $3.32 \mathrm{mS} / \mathrm{cm}$ (in comparison to K10, the conductivity of which was approximately half as high), and such salinity is found only in some types of composts produced under shelters or mineral fertilizers (Cesaro et al. 2015, Ciesielczuk et al. 2017, Golcz et Komosa 2006); therefore, it could have contributed to a soil conductivity increase in this experimental field. The highest conductivity was shown by commercial fertilizers (NJ and S); however, their components were incepted by goldenrod after 160 days of the experiment or were washed away (with precipitation) due to the lack of organic matter in their composition which could effectively absorb biogens (Mazur et al. 2011). A positive effect of the experimental fertilizers (K10 and K13) application was an increase in the content of organic matter, which increases the water capacity of soil on the one hand, as well as increases the capacity of the sorption complex and redoubles the soil microorganisms activity on the other (Poulsen et al. 2013). Moreover, no influence of the applied fertilisation on soil composition was observed 
Table 3. Characteristics of soil samples before (A) and after experiment (B)

\begin{tabular}{|c|c|c|c|c|c|c|c|}
\hline \multirow{2}{*}{ Specification } & \multirow{2}{*}{$A$} & \multicolumn{6}{|c|}{$B$} \\
\hline & & Control & K10 & K13 & $P$ & NJ & $S$ \\
\hline $\mathrm{pH}_{(\mathrm{KCl})}$ & $6.67-6.75$ & 6.30 & 6.18 & 6.25 & 6.22 & 6.20 & 6.27 \\
\hline $\mathrm{pH}_{(\mathrm{H} 2 \mathrm{O})}$ & $6.84-6.92$ & 6.59 & 6.47 & 6.55 & 6.50 & 6.43 & 6.61 \\
\hline EC [uS/cm] & 98.9 & 110 & 104 & 144 & 131 & 129 & 123 \\
\hline OM [\%] & 6.33 & 6.23 & 6.45 & 6.83 & 5.92 & 5.90 & 6.08 \\
\hline TOC $[\mathrm{g} / \mathrm{kg}]$ & 25.5 & 22.9 & 25.2 & 23.7 & 22.1 & 25.5 & 22.8 \\
\hline TN $[\% \mathrm{~N}]$ & 0.33 & 0.22 & 0.19 & 0.29 & 0.2 & 0.28 & 0.24 \\
\hline Phosphorus $\left[\% \mathrm{P}_{2} \mathrm{O}_{5}\right]$ & 0.24 & 0.35 & 0.56 & 0.47 & 0.42 & 0.65 & 0.75 \\
\hline Potassium $\left[\% \mathrm{~K}_{2} \mathrm{O}\right]$ & 0.16 & 0.16 & 0.14 & 0.18 & 0.19 & 0.20 & 0.17 \\
\hline Calcium [\% CaO] & 0.062 & 0.058 & 0.030 & 0.062 & 0.056 & 0.053 & 0.077 \\
\hline Sodium $\left[\% \mathrm{Na}_{2} \mathrm{O}\right]$ & 0.049 & 0.016 & 0.013 & 0.016 & 0.018 & 0.018 & 0.019 \\
\hline
\end{tabular}

with the exception of phosphorus, the amount of which increased from 20 to $114 \%$ in comparison to the control, but the content of this element in the previous season was lower by $0.1 \%$ in comparison to the control. Perhaps, the phosphorus is likely to be washed out slowly. The soil samples were taken in March before the experiment and at the end of August - after the experiment.

On the plots where biomass ash was used, it was expected that the reaction would increase and that the content of calcium, potassium and phosphorus would increase significantly too, which was confirmed in the field studies with miscanthus; however, this effect was observed at much higher doses (Demeyer et al. 2001, Meller and Bilenda 2012). The lack of a clear effect of ash fertilisation should be explained not only by the relatively small one-off dose, but also by the use of biogens during the growing season (160 days) and the washing up with precipitation water.

The composition of goldenrod shoots was similar for all fertilizers applied, except for nitrogen, which amount was found to be higher in the biomass taken from the NJ and S plots, which may suggest synergistic effects of highly concentrated mineral fertilizers applied on uncultivated soil (Table 4).

There were also slight differences in the sulphur content. The lowest was noted in the control sample, which is quite important in the case of biomass use for heating purposes and sulphur dioxide emission, but the content of this element in the surface part of this species may reach much higher values ranging to nearly $0.2 \%$ (Ciesielczuk et al. 2016). The value of combustion heat was also similar in all the analysed samples with the exception of biomass coming from the $\mathrm{K} 13$ and $\mathrm{S}$ plots; however, they still did not exceed $0.1 \mathrm{MJ} /$ $\mathrm{kg}$ in relation to the control sample. In the case of the plot where the simplest solution was applied, i.e. biomass ash, the value of combustion heat was the same as in the control sample, and in the case of K10, it even dropped by $0.2 \mathrm{MJ} / \mathrm{kg}$. The recorded values are slightly lower (by about $1.0-1.5 \mathrm{MJ} /$ $\mathrm{kg}$ ) in comparison to those obtained from woody biomass, which, however, does not eliminate goldenrod to be used as a source of cheap energy, especially for small farms owning or leasing setaside areas. In the case of the goldenrod from a rich site, the calorific value was higher by almost $0.5 \mathrm{MJ} / \mathrm{kg}$ (Ciesielczuk et al. 2016).

The most interesting indicator pertaining to the effectiveness of the applied fertilisation is yielding (Table 5).

In comparison to the control sample, where slightly more than $9.6 \mathrm{Mg} / \mathrm{ha}$ was recorded, the yield was higher than $15-17 \%$ in the cases of K10 and $\mathrm{P}$ to $28-29 \%$ in the cases of $\mathrm{NJ}$ and $\mathrm{S}$, re-

Table 4. Basic characteristics of plants from field experiment

\begin{tabular}{|c|c|c|c|c|c|}
\hline Specification & $\mathrm{N}[\%]$ & $\mathrm{C}[\%]$ & $\mathrm{H}[\%]$ & $\mathrm{S}[\%]$ & Combustion heat [MJ/kg] \\
\hline Control & 0.551 & 44.4 & 5.48 & 0.021 & $17.558(0.006)$ \\
\hline K10 & 0.585 & 44.0 & 5.47 & 0.033 & $17.353(0.069)$ \\
\hline K13 & 0.615 & 44.5 & 5.47 & 0.029 & $17.624(0.015)$ \\
\hline P & 0.502 & 44.5 & 5.51 & 0.029 & $17.558(0.028)$ \\
\hline NJ & 0.744 & 44.0 & 5.62 & 0.043 & $17.572(0.011)$ \\
\hline S & 0.665 & 44.7 & 5.49 & 0.030 & $17.603(0.014)$ \\
\hline
\end{tabular}


Table 5. Yield of Solidago canadensis shoots from field experiment

\begin{tabular}{|c|c|c|c|c|}
\hline Specification & Fresh shoot mass [g] & Shoot lenght [cm] & Fresh mass of yield [Mg/ha] & Energy [GJ/ha] \\
\hline Control & $14.5(7.6)$ & $120.1(21.4)$ & 9.62 & 168.9 \\
\hline K10 & $16.59(7.5)$ & $121.2(16.0)$ & 11.09 & 192.4 \\
\hline K13 & $20.1(10.4)$ & $123.4(17.3)$ & 11.57 & 203.9 \\
\hline P & $16.4(9.4)$ & $120.2(19.1)$ & 11.23 & 197.2 \\
\hline NJ & $19.8(9.3)$ & $126.6(18.1)$ & 12.39 & 217.7 \\
\hline S & $18.2(6.9)$ & $125.3(17.7)$ & 12.36 & 217.6 \\
\hline
\end{tabular}

spectively. Despite small fertilizer doses and no significant differences in the elemental composition of goldenrod biomass, the increase in yields on plots was considerable. It should be stressed that this was the first fertilization applied in the area, to which plants reacted positively. Nevertheless, it is likely that the next fertiliser doses should be higher, but due to the light soil, it should be mineral-organic fertilisation (K10 and $\mathrm{K} 13$ fertilisers). The use of organic and mineral wastes used in the production of K10 and K13 fertilizers is part of the circular economy and sustainable fertilizer management aimed at the protection of groundwater quality (Powlson et al. 2011, Rosik-Dulewska et al. 2007 Roy et al. 2013). Yielding on a plot where K13 fertilizer was applied is of a particular interest. Although the obtained yield of almost $11.6 \mathrm{Mg}$ of fresh plant matter was higher than the control by $20 \%$, a significant share of magnesium in this fertilizer should cause an even higher yield increase, which was not observed. The plants from this plot obtained the highest mass of a single shoot, which points at the positive influence of this fertilizer on plants growth. The use of ash, which caused an increase in yield by almost $17 \%$ and the energy obtained exceeded $197 \mathrm{GJ} / \mathrm{ha}$, was surprisingly positive, but the use of such a fertilizer in practice is difficult due to its dusty character. The highest amount of energy, as expected, was obtained from the plants which grew on the NJ and S plots; however, the applied commercial fertilizers should be purchased, which, unlike other applied measures, decreases the economic effectiveness of the obtained energy from the process of goldenrod burning. Similar energy efficiency was achieved in the study of the Virginia fanpetals L., which shows the appreciable potential of goldenrod that is not perceived as an energy plant (Szempliński et al. 2014). The demonstrated effectiveness of experimental fertilizers $\mathrm{K} 10$ and $\mathrm{K} 13$ in combination with low load of heavy metals predestines them to be used also as far as edible crops are concerned (Ciesielczuk et al. 2017, Lopes et al. 2011, Rosik-Dulewska et al. 2008).

\section{CONCLUSIONS}

In the field experiment carried out, small doses of two experimental fertilizers, ash biomass and two commercial fertilizers were used. The applied fertilization, regardless of the type of fertilizer, resulted in an increase in yielding by almost $29 \%$ compared to the control sample, and thus an increase in the amount of energy obtained from the collected goldenrod. Such an unusual increase in yield was probably caused by the lack of fertilization in a particular area and the barren top layer of light soil which is susceptible to nutrient leaching. Despite the fact that with the use of experimental fertilizers it was not possible to achieve a similarly strong increase of goldenrod yield as in the case of commercial fertilizers, their production, based on the use of waste generated within the farm, fits into the circulation economy and goldenrod yield increase was of $15-20 \%$. Admittedly, the cheapest solution is ash from biomass, nevertheless its components are strongly alkaline, which demands high precision of dosing, top sieving of fertilizers is not recommended because of the possibility of plants burns and additionally, in the case of light soil its components are susceptible to leaching, unlike the experimental fertilizers K10 and K13, which consist in over $90 \%$ of organic matter and their granulated form favours a slow release of components, which additionally protects groundwater against pollution.

\section{REFERENCES}

1. Ballesteros L.F.. Teixeira J.A.. Mussatto S.I. (2014). Chemical. Functional. and Structural Properties of Spent Coffee Grounds and Coffee Silverskin. Food Bioprocess Technol. 7. 3493-3503 DOI 10.1007/s11947-014-1349-Z 
2. Caetano N.S.. Silva V.M.F.. Melo A.C.. Martins A.A.. Mata T.M. (2014). Spent coffee grounds for biodiesel production and other applications. Clean Techn Environ Policy. 16. 1423-1430 DOI 10.1007/s10098-014-0773-0

3. Cesaro A.. Belgiorno V.. Guida M. (2015). Compost from organic solid waste: Quality assessment and European regulations for its sustainable use. Resources. Conservation and Recycling. 94. 72-79 http://dx.doi.org/10.1016/j.resconrec.2014.11.003

4. Ciesielczuk T.. Poluszyńska J.. Rosik-Dulewska Cz.. Sporek M. Lenkiewicz M. (2016) Uses of weeds as an economical alternative to processed wood biomass and fossil fuels. Ecological Engineering 95. 485-491 doi:10.1016/j.ecoleng.2016.06.100

5. Ciesielczuk T.. Rosik-Dulewska Cz.. Poluszyńska J.. Miłek D.. Szewczyk A.. Sławińska I. (2017). Acute Toxicity of Experimental Fertilizers Made of Spent Coffee Grounds. Waste and Biomass Valorization. DOI 10.1007/s12649-017-9980-3 .

6. Ciesielczuk T.. Rosik-Dulewska Cz.. Wiśniewska E. (2015). Possibilities of coffee spent ground use as a slow action organo-mineral fertilizer. Annual Set The Environment Protection. 17. 422-437

7. Demeyer A.. Voundi-Nkana J.C.. Verloo M.G. (2001).Characteristics of wood ash and infuence on soil properties and nutrient uptake: an overview. Bioresource Technology 77. 287-295

8. Golcz A., Komosa A. (2006).Uwalnianie się azotu fosforu i potasu z nawozu wolnodziałającego osmocote plus w uprawie papryki (Capsicum annuum L.). Acta Agrophysica. 7(3). 567-576

9. Lopes C.. Herva M., Franco-Uría A., Roca E. (2011). Inventory of heavy metal content in organic waste applied as fertilizer in agriculture: evaluating the risk of transfer into the food chain. Environ Sci Pollut Res. 18.918-939 DOI 10.1007/ s11356-011-0444-1

10. Mazur Z.. Radziemska M.. Tomaszewska Z.. Świątkowski Ł. (2013). Effect of sodium chloride salinization on the seed germination of selected vegetable plants. Scientific Review - Engineering and Environmental Sciences. 62. 444-453

11. Meller E., Bilenda E. 2012. Wpływ popiołów ze spalania biomasy na właściwości fizykochemiczne gleb lekkich. Polit. Energ. 15, 287-292

12. Mussatto S.I.. Machado E.M.S.. Martins S.. Teix- eira J.A. (2011). Production. Composition. and Application of Coffee and Its Industrial Residues. Food Bioprocess Technol. 4.661-672 DOI 10.1007/s11947-011-0565-Z

13. Poulsen P.H.B.. Magid J.. Luxhøi J.. de Neergaard A. (2013). Effects of fertilization with urban and agricultural organic wastes in a field trial - Waste imprint on soil microbial activity. Soil Biology \& Biochemistry. 57. 794-802 doi:10.1016 /j.soilbio.2012.02.031

14. Powlson D.S.. Gregory P.J.. Whalley W.R.. Quinton J.N.. Hopkins D.W.. Whitmore A.P.. Hirsch P.R.. Goulding K.W.T. (2011). Soil management in relation to sustainable agriculture and ecosystem services. Food Policy. 36. 72-87 doi:10.1016/j. foodpol.2010.11.025

15. Pujol D.. Liu C.. Gominho J.. Olivella M.À.. Fiol N.. Villaescusa I.. Pereira H. (2013). The chemical composition of exhausted coffee waste. Industrial Crops and Products.50. 423- 429 http://dx.doi. org/10.1016/j.indcrop. 2013.07.056

16. Rosik-Dulewska Cz.. Glowala K.. Karwaczyńska U.. Robak J. (2008). Elution of heavy metals from granulates produced from municipal sewage deposits and fly-ash of hard and Brown coal in the aspect of recycling for fertilization purposes. Archives of Environmental Protection.34 (2). 63-71

17. Rosik-Dulewska Cz.. Robak J.. Głowala K. (2007). Granulated organic and mineral fertilizers: Technology and utility properties. Polish Journal of Chemical Technology. 9(4). 36-39 doi: 10.2478/ v10026-007-0085-9

18. Roy M.. Karmakar S.. Debsarcar A.. Sen P.K.. Mukherjee J. (2013). Application of rural slaughterhouse waste as an organic fertilizer for pot cultivation of solanaceous vegetables in India. International Journal Of Recycling of Organic Waste in Agriculture. 2-6

19. Sampaio A.. Dragone G.. Vilanova M.. Oliveira J.M.. Teixeira J.A.. Mussatto S.I. (2013). Production. chemical characterization. and sensory profile of a novel spirit elaborated from spent coffee grodunds. LWT - Food Science and Technology. 54: 557-563 http://dx.doi.org/10.1016 /j.lwt.2013.05.042

20. Szempliński, W., Parzonka, A., Sałek, T., 2014. Yield and energy efficiency of biomass production of some species of plants grown for biogas. Acta Sci. Pol.Agric. 13 (3), 67-80. 